\title{
Korelasi Indeks Massa Tubuh dengan Profil Lipid pada Masyarakat di Jatinangor Tahun 2014
}

\author{
Zahra Humaera', Hadyana Sukandar ${ }^{2}$, Sylvia Rachmayati ${ }^{3}$ \\ ${ }^{1}$ Fakultas Kedokteran, Universitas Padjadjaran \\ ${ }^{2}$ Departemen Ilmu Kesehatan Masyarakat, Fakultas Kedokteran Universitas Padjadjaran \\ ${ }^{3}$ Departemen Patologi Klinik, Fakultas Kedokteran Universitas Padjadjaran
}

\begin{abstract}
Abstrak
Obesitas merupakan masalah epidemik. Setiap tahunnya terjadi peningkatan persentase individu dengan IMT tinggi (overweight atau obese). Beberapa penyakit tidak menular seperti hipertensi, penyakit jantung koroner (PJK) dan stroke mempunyai faktor risiko yang sama yaitu meningkatnya indeks massa tubuh dan meningkatnya konsentrasi profil lipid. Penelitian ini bertujuan untuk mengetahui korelasi antara indeks massa tubuh dengan konsentrasi profil lipid. Penelitian ini menggunakan data sekunder pendekatan studi potong lintang (cross sectional). Jumlah sampel sebanyak 99 orang. Analisis data menggunakan uji korelasi rank Spearman. Karakteristik sampel pada data yang didapatkan menunjukkan sebanyak 55\% subjek termasuk dalam golongan yang mempunyai berat badan yang berlebih (overweight dan obese). Rerata Indeks Massa Tubuh dan profil lipid lebih tinggi pada perempuan bila dibandingkan dengan laki-laki, kecuali untuk kadar TG. Koefisien korelasi IMT dengan kolesterol total (rs $=0,244 \mathrm{p}=0,015)$, dengan HDL-C $(\mathrm{rs}=-0,222 \mathrm{p}=0,027)$, dengan LDL-C $(\mathrm{rs}=0,223 \mathrm{p}=0,026)$, dan dengan TG ( $\mathrm{rs}=0,242 \mathrm{p}=0,016)$. Terdapat korelasi yang signifikan antara indeks massa tubuh dengan profil lipid.
\end{abstract}

Kata Kunci : HDL-C, IMT, Kolesterol total, LDL-C, TG

\section{Correlation between Body Mass Index and Lipid Profile in Jatinangor Society in 2014}

\begin{abstract}
Obesity is an emerging epidemical issue. The percentage of individuals with high Body Mass Index consistently escalates in every year. Non-communicable disease such as hipertension, coronary heart disease (CHD) and stroke, are influenced by risk factors. One of the important risk factors is the increasing BMI and high concentration of lipid profile. The aim of this study is to discover the causal inference between BMI and concentration of lipid profile. Cross-sectional design was conducted in this study. Sample subjects consisted of 99 individuals. Obtained data were analyzed using Spearman's Rank correlation test. Characteristic of subjects from the obtained data showed that as much of 55\% of the subjects were having overly high BMI (overweight and obese). Mean of BMI and lipid profile in female were higher compared to male except for male Triglyceride was higher rather than female. Significant correlation was found between BMI and total cholesterol ( $r s=0.244 p=0.015)$, BMI and High Density Lipoprotein-Cholesterol ( $r s=-0.222 p=0.027)$, BMI and Low Density Lipoprotein-Cholesterol $(r s=0.223 p=$ 0.026), BMI and Triglyceride ( $r s=0.242 p=0.016)$. There was significant correlation between BMI and lipid profile.
\end{abstract}

Keyword : BMI, HDL-C, LDL-C, TG, Total Cholesterol

Korespondensi:

Zahra Humaera

Fakultas Kedokteran Universitas Padjadjaran

Jl. Raya Bandung-Sumedang KM 21 Jatinangor, Sumedang

Mobile : 081221899530

Email : zahrahumaera12@gmail.com 


\section{Pendahuluan}

Indeks Massa Tubuh (IMT) merupakan sebuah indeks nilai yang didapatkan dari pengukuran antropometri berat badan dalam satuan kilogram $(\mathrm{kg})$ dibagi dengan tinggi badan dengan satuan meter kuadrat $\left(\mathrm{m}^{2}\right)$, indeks ini digunakan untuk mengkategorikan individu tergolong dalam kategori berat badan kurang, normal atau lebih. Indeks Massa Tubuh ini walaupun tidak mengukur kadar lemak secara langsung seperti underwater weighting dan dual energy x-ray absorptiometry, tetapi IMT merupakan salah satu cara skrining yang mudah dan tidak invasif untuk menggambarkan kadar lemak dalam tubuh. World Health Organization (WHO) mengklasifikasikan indeks massa tubuh menjadi beberapa kategori underweight, normal, overweight dan obese, sedangkan IMT untuk Asia Pasifik mempunyai kategori tersendiri yaitu terdiri dari 3 kategori; underweight, normal dan overweight yang dibagi menjadi 3 kategori; Overweight yang berisiko, Obese I, dan Obese II. ${ }^{1,2}$ Indeks Massa Tubuh dapat digunakan sebagai salah satu parameter untuk mengukur besarnya risiko seseorang terkena penyakit tertentu seperti hipertensi, dislipidemia, penyakit jantung koroner (PJK) dan stroke. ${ }^{3,4}$ Terdapat beberapa faktor yang dapat memengaruhi indeks massa tubuh diantaranya adalah adanya pengaruh genetik dan lingkungan..$^{5-7}$ Jika dalam satu keluarga orang tua memiliki indeks massa tubuh dalam kategori berat badan lebih keturunannya mempunyai predisposisi memiliki IMT kategori sama. ${ }^{6}$

Obesitas merupakan masalah epidemik, menurut Riset Kesehatan Dasar (Riskesdas) 2013 pada kelompok laki-laki dewasa prevalensi obesitas pada tahun 2013 meningkat 11,9\% dari tahun 2010, sedangkan prevalensi obesitas pada kelompok perempuan dewasa meningkat 17,5\% dari tahun 2010. ${ }^{8-10}$ Berat badan berbanding lurus dengan jumlah lemak dalam darah, seseorang dengan berat badan yang berlebih memiliki risiko tinggi meningkatnya jumlah lemak dalam darah. ${ }^{11}$ Masalah kelebihan berat badan ini merupakan masalah yang dapat dicegah, jika hal ini dapat dikendalikan akan menurunkan risiko hipertensi, PJK, dan stroke. ${ }^{4}$ Beberapa penyakit tersebut mempunyai faktor risiko yang sama yaitu tingginya indeks massa tubuh dan tingginya konsentrasi profil lipid dalam darah. ${ }^{12,13}$ Profil lipid merupakan suatu gambaran komposisi lipid dalam darah yang terbagi menjadi 4 komponen, kolesterol total, High Density Lipoprotein Cholesterol (HDL-C), Low Density Lipoprotein Cholesterol (LDL-C), dan trigliserida (TG). Penentuan cut off profil lipid merujuk pada National Cholesterol Education Program-Adult
Treatment Panel III (NCEP-ATP III), dengan nilai kolesterol total $<200 \mathrm{mg} / \mathrm{dL}, \mathrm{LDL}-\mathrm{C}<100$ $\mathrm{mg} / \mathrm{dL}$, HDL-C $\geq 60 \mathrm{mg} / \mathrm{dL}$, dan TG $<150 \mathrm{mg} /$ dL. ${ }^{14}$ Tujuan dari penelitian ini untuk mengetahui korelasi antara indeks massa tubuh dengan profil lipid, jika terdapat korelasi diharapkan penelitian ini dapat menjadi dasar edukasi pada masyarakat untuk mencegah obesitas dan komplikasi yang dapat terjadi karena obesitas seperti hipertensi, penyakit jantung koroner dan stroke.

\section{Metode}

Penelitian ini dilakukan dengan pendekatan studi potong lintang. Peneliti menggunakan data sekunder yang diambil dari penelitian "Pencegahan Primer dan Sekunder Terhadap Hipertensi Pada Masyarakat Jatinangor" yang dilakukan oleh Pusat Studi Kesehatan dan Kebugaran Komunitas tahun 2014, dengan sampel yang didapatkan dari satu desa yang pemilihannya berdasarkan metode acak berstrata (multistage sampling). Variabel yang dibutuhkan diambil untuk diketahui korelasinya seperti identitas subjek, berat badan, tinggi badan, kolesterol total, HDL-C, LDL-C, dan TG. Kriteria inklusi pada penelitian ini adalah subjek bertempat tinggal di Kecamatan Jatinangor dan berusia diatas 18 tahun. Kriteria ekslusinya adalah subjek sedang atau mempunyai riwayat penyakit stroke atau penyakit jantung koroner, olahragawan, ibu hamil dan data tidak lengkap. Ukuran sampel minimal yang dibutuhkan dalam penelitian ini sebanyak 215 dengan $\alpha=5 \% \beta=20 \%$ $r=0,19$ orang yang ditentukan berdasarkan rumus penelitian analitik korelasi.

Data didapatkan dari Pusat Studi Kesehatan dan Kebugaran Komunitas dengan terlebih dahulu membuat surat perizinan amandemen etik ke Komite Etik Penelitian Kesehatan Fakultas Kedokteran Universitas Padjadjaran. Penelitian ini dimulai dengan mengubah variabel berat badan dan tinggi badan menjadi variabel indeks massa tubuh dengan dengan cara; berat badan dalam kilogram dibagi tinggi badan dalam meter kuadrat $\left(\mathrm{kg} / \mathrm{m}^{2}\right)$. Indeks massa tubuh diklasifikasikan menjadi 3 kategori; underweight $\left(<18,5 \mathrm{~kg} / \mathrm{m}^{2}\right)$, normal $\left(18,50-22,9 \mathrm{~kg} / \mathrm{m}^{2}\right)$, overweight $(\geq 23,00$ $\mathrm{kg} / \mathrm{m} 2$ ), overweight dibagi menjadi 3 kategori; Overweight yang berisiko $\left(23-24,9 \mathrm{~kg} / \mathrm{m}^{2}\right)$, Obese I $\left(25-29,9 \mathrm{~kg} / \mathrm{m}^{2}\right)$, dan Obese II $\left(\geq 30 \mathrm{~kg} / \mathrm{m}^{2}\right)$

Analisis data dilakukan dengan bantuan IBM Software Statistical Product and Service Solution (SPSS) versi 20 untuk sistem operasi Windows. Korelasi antara indeks massa tubuh dan konsentrasi profil lipid dianalisis dengan menggunakan uji korelasi rank Spearman. Hasil 
dinyatakan bermakna secara statistik jika nilai $\mathrm{p}$ $<0,05$.

\section{Hasil}

Hasil analisis data disajikan dalam bentuk tabel. Tabel 1 menunjukkan karakteristik subjek berdasarkan usia, jenis kelamin, pendidikan, dan indeks massa tubuh. Subjek terdiri dari 68 orang perempuan $(68,6 \%)$ dan 31 orang lakilaki $(31,3 \%)$. Analisis data dilakukan untuk mengetahui karakteristik subjek dan didapatkan 34 subjek memiliki IMT kategori obese I, dan sebanyak 18 responden berada dalam kategori IMT normal dan sisanya termasuk dalam kategori underweight, overweight at risk dan obese II. Responden terbanyak pada kategori usia diatas 60 tahun, perempuan dan dalam kategori obese I.

Tabel 1 Karakteristik subjek

\begin{tabular}{|c|c|}
\hline Karakteristik & Jumlah n (\%) \\
\hline \multicolumn{2}{|l|}{ Usia (th) } \\
\hline $20-29$ & $3(3,0)$ \\
\hline $30-39$ & $11(11,1)$ \\
\hline $40-49$ & $7(7,1)$ \\
\hline $50-59$ & $19(19,2)$ \\
\hline$\geq 60$ & $59(59,6)$ \\
\hline \multicolumn{2}{|l|}{$\overline{\mathrm{X}}(\mathrm{SD})=59,7(13,98)$} \\
\hline \multicolumn{2}{|l|}{ Rentang $=23-82$} \\
\hline \multicolumn{2}{|l|}{ Jenis Kelamin } \\
\hline Laki-laki & $31(31,3)$ \\
\hline Perempuan & $68(68,7)$ \\
\hline \multicolumn{2}{|l|}{ Pendidikan } \\
\hline $\mathrm{SD}$ & $53(53,5)$ \\
\hline SMP & $27(27,3)$ \\
\hline SMA & $17(17,2)$ \\
\hline Perguruan Tinggi & $2(2,0)$ \\
\hline \multicolumn{2}{|l|}{ Indeks Massa Tubuh $\left(\mathrm{kg} / \mathrm{m}^{2}\right)$} \\
\hline Underweight $(<18,50)$ & $9(9,1)$ \\
\hline Normal $(18,50-22,9)$ & $18(18,2)$ \\
\hline Overweight at risk $(23-24,9)$ & $17(17,2)$ \\
\hline Obese I $(25-29,9)$ & $34(34,3)$ \\
\hline Obese II $(\geq 30)$ & $21(21,2)$ \\
\hline \multicolumn{2}{|l|}{$\overline{\mathrm{X}}(\mathrm{SD})=25,8(4,77)$} \\
\hline Rentang $=15,19-36,76$ & \\
\hline
\end{tabular}

Tabel 2 menunjukkan hasil pengukuran profil lipid pada laki-laki, perempuan dan kelompok gabungan. Analisis data dilakukan dengan mencari rerata, standar deviasi, medium dan rentang. Hasil analisis menunjukkan bahwa rerata dan median kolesterol total pada kelompok jenis kelamin laki-laki dan perempuan termasuk dalam kategori optimal $(<200 \mathrm{mg} / \mathrm{dL})$, rerata tertinggi pada kelompok perempuan (194,6 $\mathrm{mg} / \mathrm{dL}$ ). Sedangkan rerata dan median LDL-C pada dua kelompok tersebut berada dalam kategori mendekati optimal (100 mg/dL-129 $\mathrm{mg} / \mathrm{dL}$ ), dengan rerata tertinggi pada kelompok perempuan $(126,6 \mathrm{mg} / \mathrm{dL})$. Rerata dan median HDL-C pada dua kelompok tersebut cenderung normal-rendah yaitu rendah dalam rentang $<40$ $\mathrm{mg} / \mathrm{dL}$ pada kelompok laki-laki dan normal pada kelompok perempuan $>40 \mathrm{mg} / \mathrm{dL}$ tetapi $\leq 60 \mathrm{mg} /$ dL. Rerata trigliserida pada dua kelompok jenis kelamin berada pada kategori optimal $(<150 \mathrm{mg} /$ dL) dengan rerata dan median lebih tinggi pada kelompok laki-laki (147,0 mg/dL).

Analisis data korelasi menggunakan perhitungan analisis koefisien korelasi rank Spearman (Tabel 3). Tabel tersebut tampak menunjukkan adanya korelasi positif yang lemah dan bermakna antara indeks massa tubuh dengan kolesterol total $(\mathrm{rs}=0,244 \mathrm{p}=0,015)$, IMT dengan LDL-C ( $r s=0,223 p=0.026)$, dan IMT dengan TG $(\mathrm{rs}=0,242 \mathrm{p}=0,016)$. Sedangkan korelasi negatif yang lemah bermakna antara IMT dengan HDL-C yaitu $(\mathrm{rs}=-0,222 \mathrm{p}=0,027)$.

\section{Pembahasan}

Pada penelitian ini, korelasi antara indeks massa tubuh dengan profil lipid menggunakan subjek populasi masyarakat Jatinangor, sampel didapatkan dari satu desa yang pemilihannya menggunakan metode acak berstrata (multistage sampling), sampel yang diambil adalah subjek yang memenuhi kriteria inklusi dan tidak termasuk dalam kriteria eksklusi, dari sebanyak 99 data yang diuji, didapatkan bahwa terdapat korelasi positif yang signifikan antara indeks massa tubuh dengan kolesterol total, LDL-C dan TG. Hasil ini sesuai dengan penelitian yang dilakukan oleh Zinah dan Mahmood pada populasi wanita premenopouse dengan diabetes. ${ }^{15}$

Berdasarkan hasil uji terdapat korelasi negatif antara indeks massa tubuh dengan HDL-C, hasil penelitian yang sama didapatkan dari penelitian pada populasi sampel morbidly obese di Florida oleh Shamai dkk, terdapat korelasi IMT dengan HDL-C dan TG. ${ }^{16}$

Penelitian yang sama pernah dilakukan di Indonesia dengan subjek penelitian pada karyawan perusahaan swasta di Padang, hasil analisis data menunjukkan terdapat korelasi 
Tabel 2 Hasil Pengukuran Profil Lipid

\begin{tabular}{cccc}
\hline Profil Lipid (mg/dL) & $\begin{array}{c}\text { Laki-laki } \\
\mathbf{n}=\mathbf{3 1}\end{array}$ & $\begin{array}{c}\text { Perempuan } \\
\mathbf{n}=\mathbf{6 8}\end{array}$ & $\begin{array}{c}\text { Gabungan } \\
\mathbf{n}=\mathbf{9 9}\end{array}$ \\
\hline Kolesterol Total & & & \\
$\bar{X}(\mathrm{SD})$ & $188,6(41,7)$ & $194,6(41,9)$ & $192,7(41,7)$ \\
Medium & 182,3 & 188,3 & 188,20 \\
Rentang & $111,0-276,4$ & $124,0-310,5$ & $111,0-310,5$ \\
LDL-C & & & \\
$\bar{X}$ (SD) & $123,4(39,9)$ & $126,6(33,9)$ & $125,6(35,7)$ \\
Medium & 120,0 & 120,15 & 120,0 \\
Rentang & $38,80-222,80$ & $67,60-240,0$ & $38,80-240,0$ \\
HDL-C & & & $40,97(12,96)$ \\
$\bar{X}(\mathrm{SD})$ & $37,5(12,7)$ & $42,52(12,8)$ & 40,10 \\
Medium & 35,0 & 41,0 & $17,40-86,3$ \\
Rentang & $19,0-85,1$ & $17,4-83,6$ & $136,78(79,18)$ \\
TG & & & 113,0 \\
$\bar{X}(\mathrm{SD})$ & $147,0(90,2)$ & $132,1(73,8)$ & $48,60-504,6$ \\
\hline
\end{tabular}

Tabel 3 Korelasi IMT dengan Profil lipid

\begin{tabular}{ccc}
\hline Korelasi IMT dengan & $\mathbf{r}_{\mathbf{s}}$ & Gabungan \\
\hline Kolesterol Total & 0,244 & $\mathbf{p}$ \\
LDL-C & 0,223 & 0,015 \\
HDL-C & $-0,222$ & 0,026 \\
TG & 0,242 & 0,027 \\
\end{tabular}

Keterangan:

$\mathrm{r}_{\mathrm{s}}$ : koefisien korelasi rank Spearman

p: nilai signifikansi (dinyatakan signifikan jika $\mathrm{p}<0,05$ )

positif indeks massa tubuh dengan konsentrasi kolesterol total dan trigliserida dan tidak berkorelasi dengan kadar LDL-C dan HDL-C. ${ }^{17}$ Penelitian yang sama dengan subjek yang berbeda yaitu pada pasien diabetes melitus tipe 2 di Manado menunjukan terdapat korelasi indeks massa tubuh dengan HDL-C. ${ }^{18}$

Hasil penelitian ini didapatkan adanya korelasi yang signifikan antara indeks massa tubuh dengan konsentrasi profil lipid. Perbedaan hasil analisis data dengan penelitian yang sama yang pernah dilakukan, dapat diakibatkan karena adanya perbedaan karakteristik subjek, waktu pengambilan sampel penelitian dan halhal lain yang dapat memengaruhi korelasi IMT dengan konsentrasi profil lipid (adanya kelainan metabolime). Metabolisme lipid pada individu normal pada keadaan fed state jumlah insulin akan meningkat dalam sirkulasi diikuti dengan adanya sensitivitas jaringan terhadap insulin, hal ini akan mengaktivasi enzim lipoprotein lipase (LPL) sehingga lemak dapat disimpan di jaringan adiposa sebagai cadangan energi atau di reesterifikasi kembali menjadi triglisedrida di liver dan ditranspor dalam bentuk lipoprotein VLDL, sehingga konsentrasi VLDL akan meningkat dalam sirkulasi. Sebaliknya dalam keadaan fasting state jumlah insulin dalam sirkulasi akan rendah, tetapi sensitivitas jaringan terhadap insulin akan tetap normal hal ini akan menghambat aktivasi enzim lipoprotein lipase dan mengaktivasi enzim hormone sensitive lipase yang menyebabkan meningkatkan pelepasan asam lemak bebas ke dalam sirkulasi. ${ }^{19}$ 
Meningkatnya indeks massa tubuh (overweight atau obese) atau disebut juga dengan adiposity disebabkan oleh meningkatnya akumulasi lemak. Saat intake lebih besar dibanding dengan expenditure terjadi positive energy balance yang dipengaruhi oleh faktor genetik dan lingkungan. Meningkatnya adiposity menyebabkan hipertropi sel adiposit yang berlebihan yang dapat menstimulasi sel dan jaringan adiposit untuk memberikan respon patogen sehingga dapat menyebabkan gangguan fungsi organel (mitokondria dan retikulum endoplasma), disregulasi hormonal, terganggunya penyimpanan asam lemak bebas dan meningkatnya resistensi jaringan terhadap insulin, hal ini akan mengganggu metabolisme asam lemak dalam darah. Insulin akan tetap diproduksi tetapi jaringan akan resisten terhadap insulin, maka seluruh aktivitas hormonal yang dikontrol insulin akan berjalan normal, glukoneogenesis akan terhambat, dan meningkatnya stimulasi sintesis asam lemak bebas di liver. Resistensi jaringan terhadap insulin menyebabkan tubuh seolah-olah dalam keadaan fasting yang akan menyebabkan terjadi cell starvation akibatnya teraktivasinya enzim hormone sensitive lipase untuk meningkatkan lipolisis TG intraadiposit yang berakibat meningkatnya pelepasan asam lemak bebas di sirkulasi. ${ }^{6,19,20}$

Adiposity akan menyebabkan menurunnya fungsi adipogenesis (proliferasi dan differensiasi sel lemak) pada jaringan adiposa subkutan perifer, diikuti dengan terbatasnya ruang penyimpanan lemak di jaringan adiposa hal ini menyebabkan meningkatnya asam lemak bebas di sirkulasi, asam lemak akan disimpan pada jaringan non-lemak seperti pada organ viseral, perikardiak dan liver. Meningkatnya asam lemak di liver menyebabkan meningkatnya sekresi VLDL yang kaya TG ke sirkulasi, hal ini menyebabkan meningkatkan konsentrasi TG dalam darah. VLDL ini akan mengalami reaksi pertukaran enzimatik dengan lipoprotein lain seperti HDL dan LDL dengan bantuan enzim cholesteryl ester transferase (CETP), akibatnya terjadi interaksi VLDL dengan lipoprotein lipase yang menyebabkan terbentuknya LDL yang lebih kecil dan padat, dan ukuran HDL akan lebih kecil dengan meningkatnya jumlah apolipoprotein A-1 yang akan berikatan dengan megalincubilinamnionless system sehingga akan dimetabolisme di epitel tubulus proximal dan disekresikan melalui urin, yang menyebabkan konsentrasi HDL-C menurun dalam sirkulasi. ${ }^{6,19,21}$

Banyak faktor yang memengaruhi indeks massa tubuh dan konsentrasi profil lipid, sehingga korelasi antara IMT dengan profil lipid dipengaruhi oleh beberapa faktor seperti usia, jenis kelamin, asupan makanan, variasi biologis saat pengambilan sampel, fasting/non fasting, postur tubuh, penggambilan dari vena atau kapiler dan penyimpanan sampel. ${ }^{21,22}$

Keterbatasan penelitian ini adalah peneliti tidak mendapatkan sampel sesuai dengan ukuran sampel minimal, hal ini diakibatkan karena sampel yang tersedia hanya berasal dari satu desa dan data yang lengkap sebanyak 99 orang. Peneliti tidak dapat mengontrol faktor perancu saat pengambilan data tinggi badan, berat badan dan sampel darah karena data merupakan data sekunder, hal ini juga membatasi peneliti untuk melihat karakteristik faktor risiko yang berpengaruh terhadap meningkatnya IMT dan konsentrasi profil lipid. Tidak lengkapnya karakteristik subjek seperti data pekerjaan, penghasilan, dan asupan nutrisi menjadi keterbatasan penelitian ini.

Indeks Massa Tubuh merupakan alat skrinning lemak tubuh, tetapi untuk menggambarkan lemak tubuh lebih baik jika diukur dengan menggunakan bioelectrical impedance analysis (BIA) karena lebih berkorelasi dengan konsentrasi profil lipid (Kolesterol total, LDL-C, dan TG) kecuali dengan serum HDL-C. ${ }^{23}$ Oleh sebab itu, akan lebih baik pada penelitian selanjutnya peneliti mencari korelasi total lemak tubuh dengan profil lipid dengan menggunakan bioelectrical impedance analysis, atau dengan menggunakan ukuran nilai lingkar lengan atas. ${ }^{24}$ Nilai indeks massa tubuh yang tinggi dapat diakibatkan karena meningkatnya intake dibandingkan dengan expenditure, maka dari itu pada penelitian selanjutnya dapat dicari karakteristik nutritional intake pada individu dengan IMT tinggi.

Berdasarkan hasil penelitian dan pembahasan dapat diambil kesimpulan terdapat korelasi positif yang lemah signifikan antara indeks massa tubuh dengan konsentrasi kolesterol total, LDL-C, dan trigliserida semakin tinggi indeks massa tubuh semakin tinggi konsentrasi kolesterol total, LDL-C dan trigliserida. Sedangkan terdapat korelasi negatif yang signifikan antara indeks massa tubuh dengan konsentrasi HDL-C semakin tinggi indeks massa tubuh semakin rendah konsentrasi HDL-C.

\section{Daftar Pustaka}

1. WHO. BMI classification 2016

2. Organization WH. The Asia-Pacific perspective: redefining obesity and its treatment. 2000.

3. Farin HM, Abbasi F, Reaven GM. Comparison of body mass index versus waist circumference with the metabolic changes 
that increase the risk of cardiovascular disease in insulin-resistant individuals. The American journal of cardiology. 2006;98(8):1053-6.

4. WHO. Obesity and overweight 2016

5. Esma Asil MSS, Funda Pinar Cakiroglu, Asli Ucar, Ayse Ozfer Ozcelik, Mustafa Volkan Yilmaz and Lale Sariye Akan. Factors That Affect Body Mass Index of Adults. Pakistan Journal of Nutrition. 2014;13(5):255-60.

6. Rolfes ENWSR. Weight Management: Overweight, Obesity, and Underweight. In: Peggy Williams NR, Elesha Feldman, Alexis Glubka, Lauren Tarson, editor. Understanding Nutrition. 12th ed: Australia ; Belmont, CA : Wadsworth, Cengage Learning, C2013; 2011. p. 270-310.

7. Musaiger AO. Overweight and obesity in the Eastern Mediterranean Region. Eastern Medditerranean Health Journal; 10(6): 789793.

8. Riset Kesehatan Dasar. Indonesia. Jakarta: Badan Penelitian dan Pengembangan; 2013.

9. Mitchell N, Catenacci V, Wyatt HR, Hill JO. OBESITY: OVERVIEW OF AN EPIDEMIC. The Psychiatric clinics of North America. 2011;34(4):717-32.

10. Raine KD. Obesity epidemics: inevitable outcome of globalization or preventable public health challenge? International journal of public health. 2012;57(1):35-6.

11. Al-Ajlan AR. Lipid Profile in Relation to Anthropometric Measurements among College Male Students in Riyadh, Saudi Arabia: A Cross-Sectional Study. International Journal of Biomedical Science : IJBS. 2011;7(2):112-9.

12. Organization WH. Obesity: Preventing and Managing the Global Epidemic: World Health Organization

13. Kamso S. Body mass index, total cholesterol, and ratio total to HDL cholesterol were determinants of metabolic syndrome in the Indonesian elderly. Medical Journal of Indonesia. 2007;16(3):195.

14. National Cholesterol Education Program . Expert Panel on Detection E, Adults ToHBCi. Third Report of the National Cholesterol Education Program (NCEP) Expert Panel on Detection, Evaluation, and Treatment of High Blood Cholesterol in Adults (adult Treatment Panel III): Final Report: National Cholesterol Education Program, National Heart, Lung, and Blood Institute, National Institutes of Health

15. Ali ZAUA, Al-Zaidi MS. The Association Between Body Mass Index, Lipid Profile and Serum Estradiol Levels in a Sample of Iraqi Diabetic Premenopausal Women. Oman Medical Journal. 2011;26(4):263-6.

16. Shamai L, Lurix E Fau - Shen M, Shen M Fau - Novaro GM, Novaro Gm Fau - Szomstein S, Szomstein S Fau - Rosenthal R, Rosenthal R Fau - Hernandez AV, et al. Association of body mass index and lipid profiles: evaluation of a broad spectrum of body mass index patients including the morbidly obese.

17. Nadiah I. Hubungan Indeks Massa Tubuh dengan Profil Lipid Pada Karyawan PT TELKOM PADANG: Universitas Andalas; 2015.

18. Koampa PH, Pandelaki K, Wongkar MC. Hubungan indeks massa tubuh dengan profil lipid pada pasien diabetes melitus tipe 2 . e-CliniC. 2016;4(1).

19. Bays HE, Toth PP, Kris-Etherton PM, Abate N, Aronne LJ, Brown WV, et al. Obesity, adiposity, and dyslipidemia: a consensus statement from the National Lipid Association. Journal of clinical lipidology. 2013;7(4):304-83.

20. Singla P, Bardoloi A, Parkash AA. Metabolic effects of obesity: A review. World Journal of Diabetes. 2010;1(3):76-88.

21. Richard McPherson MP. Lipid and Dyslipoproteinemia. HENRY'S CLINICAL DIAGNOSIS AND MANAGEMENT By Laboratory Methods, Twenty-Second Edition. 22th ed. China: Elsevier Saunders; 2011. p. 1568.

22. Cooper GR, Myers GL, Smith SJ, Schlant RC. Blood lipid measurements: variations and practical utility. Jama. 1992;267(12):165260.

23. Nagaya T, Yoshida H, Takahashi H, Matsuda Y, Kawai M. Body mass index (weight/height 2) or percentage body fat by bioelectrical impedance analysis: which variable better reflects serum lipid profile? International Journal of Obesity \& Related Metabolic Disorders. 1999;23(7).

24. Manjareeka M, Nanda S, Mishra J, Mishra S. Correlation between anthropometry and lipid profile in healthy subjects of Eastern India. Journal of Mid-Life Health. 2015;6(4):164-8. 